UDC $630 * 173 / 174: 631.811 .98$

\title{
THE EFFECTIVENESS OF NATURAL GROWTH STIMULANTS IN THE CULTIVATION OF SEEDLINGS OF PICEA OBOVATA LEDEB.
}

\author{
(C) T.V. Khurshkainen ${ }^{I^{*}}$, S.K. Stetsenko ${ }^{2}$, E.M. Andreeva ${ }^{2}$, G.G. Terekhov ${ }^{2}$, A.V. Kutchin ${ }^{1}$ \\ ${ }^{1}$ Institute of Chemistry, Komi Scientific Center, Ural Branch of the Russian \\ Academy of Sciences, ul. Pervomaiskaya, 48, Syktyvkar, 167000 (Russia), \\ e-mail: hurshkainen@chemi.komisc.ru \\ ${ }^{2}$ Botanical Garden of the Ural Branch of the Russian Academy of Sciences, \\ ul. Bilimbaevskaya, 32a, Ekaterinburg, 620134 (Russia)
}

Picea obovata Ledeb. is a slow-growing in the early stages of growth type of coniferous trees. The use of growth stimulants in the cultivation of spruce seedlings can accelerate the production of standard planting material. The paper presents the results of research of plant growth regulators influence on spruce seedlings within three years of cultivation in forest nursery conditions. Before sowing seeds of spruce soak in solutions of biological-active preparations Verva and Verva-spruce, obtaining from Abies and Picea wood greenery extracts. The plants growth regulator Verva from Abies needles (operating substance triterpenic acids) is applied in plant growing at cultivation agricultural and commercial crops. Operating substance of a preparation Verva-spruce used for protection of agricultural plants from diseases, are phenolic compounds of Picea wood greenery possessing fungicidal and insecticidal activity.

It is established that spruce seedlings processed before sowing by bio-preparation had higher parameters of growth (seedling height, diameter of seedling tree at root neck) in comparison with control plants within three years of cultivation in conditions of forest nursery. Three-year spruce seedlings which have been grown up with use of growth stimulators Verva and Verva-spruce exceeded control on $20-30 \%$ on height and on $19-20 \%$ on seedling tree thickness.

Bio-preparations Verva and Verva-spruce can be recommended for application in forest nurseries as effective growth stimulators at cultivation of Siberian spruce landing material.

Keywords: Picea obovata Ledeb., natural growth regulators, seedlings, forest nursery.

This work was supported by the Ministry of Science and Higher Education of the Russian Federation (State task no. AAAA-A21-121011190042-0) and performed within the State task of the Botanical garden of the Urals branch of $R A S$.

\section{Introduction}

In modern agricultural practice, natural plant growth regulators are successfully used. The prospect of their use is determined by environmental safety, multifunctionality of action, including the ability to reduce a variety of stressful environmental effects on plants.

Khurshkainen Tatiana Vladimirovna - PhD (Chemistry), Senior Researcher, e-mail: hurshkainen@chemi.komisc.ru Stetsenko Svetlana Karlenovna - PhD (Biology), researcher, Laboratory of reforestation, forest protect and forest management, e-mail: stets_s@mail.ru Andreeva Elena Mikhailovna - PhD (Biology), senior researcher, Laboratory of reforestation, forest protect and forest management, e-mail: e_m_andreeva@mail.ru Terekhov Gennady Grigorievich - DSc (Agriculture), leading researcher, Laboratory of reforestation, forest protect and forest management, e-mail: terekhov_g_g@mail.ru Kutchin Alexander Vasilievich - DSc in chemistry, is a Professor of Organic Chemistry and a corresponding member of the Russian Academy of Sciences, e-mail: kutchin-av@chemi.komisc.ru
Plant growth regulators Verva and Vervaspruce refer to such biological products [1]. They are recommended for use on many crops to induce longterm nonspecific resistance to diseases, improve the function of the conductive system of plants and supply the above-ground part with nutrients, enhance the outflow of photosynthesis products from leaves to root system. Natural plant growth regulators contribute to the activation of photosynthetic processes while increasing the chlorophyll content in plants, which generally leads to an increase in crop productivity [2-5]. They are low toxic to humans, plants and beneficial

\footnotetext{
${ }^{*}$ Corresponding author.
} 
soil microflora. The use of natural growth regulators helps to reduce the frequency of treatment with synthetic fungicides. The introduction of such environmentally friendly products in forestry activities is in line with the concept of limiting the use of pesticides in forestry, which is supported by many countries [6].

The use of growth stimulators can become an additional element of the seedlings growing technology (protocol) for regional nurseries. The adaptability of the obtained planting material to the specific regional conditions or even to the conditions of a small area where the creation of the forest crops is planned will be increased, therefore. A similar approach to the growth of the seedlings in forest nurseries is being developed and discussed in a number of scientific studies [7, 8].

Coniferous raw material is a source of biologically active compounds with immunostimulating, fungicidal, bactericidal activity. The ability of coniferous extracts to resist the development of mold fungi, as well as fungi that cause cancer of trees, has been established [9].

The plant growth regulator Verva is a natural biological product based on substances extracted from woody greenery of Abies. Active ingredient of plant growth regulator Verva is triterpenic acids of Abies wood greenery, which stimulate seed germination, plant growth and development, increase drought and frost resistance, reduce the incidence of fungal and bacterial diseases [10]. The mode of action of triterpene acids of Abies is to activate genetic processes leading to an increase of plant immunity to a complex of diseases, to activate stress resistance genes, and thus the synthesis of substances whose function is to organize connection between environmental factors and the activity of individual genes or their blocks. The physiological activity of triterpene acids manifests in bringing out seeds from deep rest and stimulating their germination by initiating cell stretching in the root, coleoptile, and then in the stems and leaves [11]. The potential ability of compounds from the terpenoid group to carry out protective reactions in plants was noted earlier [12].

Natural phenolic compounds extracted from woody greenery of Picea are the active ingredients of the growth regulator Verva-spruce. In low concentrations it has a stimulating effect on plant growth, antibacterial influence against phytopathogenic fungi and bacteria $[13,14]$.

Improvement of agricultural technology of growing planting material of conifers and reducing its cost remains a relevant objective. The technology for producing seedlings of coniferous plants actively uses the method of stimulating growth processes, which in some cases can neutralize the consequences of possible adverse environmental factors leading to a decrease in the quality of planting material obtained in forest nurseries $[15,16]$. Environmentally safe methods of growing conifers (spruce, pine, larch, cedar, fir, etc.) can be based on the use of growth stimulants at various stages of seedling development - in seed treatment before sowing and foliar treatment of plants $[17,18]$.

Previously, drugs Verva and Verva-spruce were successfully tested on agricultural crops $[14,19]$. The prospect of using these drugs in the technology of growing Pinus sylvestris seedlings were confirmed on sprouts and one- and two-year-old seedlings [20,21]. A distinctive feature of coniferous plants are longer periods of their growth in nursery conditions and, therefore, prolonged effects of exposure to substances used to nourish and protect the soil and seedlings. Spruce at the initial stages of development is a slow-growing breed: the period of its growth in the forest nursery to reach standard sizes is $3-4$ years [15,22]. For a possible reduction of time for cultivation of standard planting spruce material with planned yield, the use of drugs that stimulate plant growth can be a good solution.

The purpose of this work is to study the effect of biological product Verva based on triterpene acids and flavonoids on the growth of Picea obovata Ledeb. in conditions of forest nursery during the full cycle of growing seedlings.

\section{Objects and methods}

Studies were carried out in the Berezovsky production nursery of the Berezovsky forestry (Sverdlovsk region, $17 \mathrm{~km}$ from city Yekaterinburg), located in the subzone of the southern taiga forests of the Middle Urals. The soil of the field is sod-podzolic medium-loamy [23]. The experimental area was created in 2016. Seedlings were grown for three years. Statistical data of weather indicators calculated from May to September showed that conditions of the growing seasons of 2017 and 2018 were aligned and remained within the average climatic values - the air temperature was +14.2 and $+14.7{ }^{\circ} \mathrm{C}$, resp. The 2016 vegetative season was warmer (average temperature $+17.1^{\circ} \mathrm{C}$ ) with lower precipitation $(164 \mathrm{~mm})$ than in subsequent years (329 $\mathrm{mm}$ in 2017 and $280 \mathrm{~mm}$ in 2018). 
In experimental variants the seeds of Picea obovata before sowing were soaked for 6 hours in solutions of Verva and Verva-spruce with concentrations of 0.1 and $0.25 \mathrm{ml}$ per kilogram of seeds, in a control variant - in distilled water. The preparations were dissolved in water, $10 \mathrm{~g}$ of seeds were soaked in $50 \mathrm{ml}$ of working solution (for $1 \mathrm{~kg}$ of seeds the volume of working solution is $5 \mathrm{l}$ ).

Caring for crops included weeding and loosening the soil. At the end of each growing season, some of them were dug out and the following parameters were measured: stem diameter at the level of a root collar, stem height, length of the stem with needles and length of the primary root. After that, the seedlings were divided into parts and dried at a temperature of $105{ }^{\circ} \mathrm{C}$ to a completely dry state and weighed with an accuracy of $0.01 \mathrm{~g}$.

Statistical processing of the data was performed using Statistica 6.0. In the analysis of these morphometric parameters (diameter, height, length of a stem with needles, length of a primary root, mass of the above-ground and underground parts of seedlings), the arithmetic mean and standard error were calculated. The obtained data in samples correspond to normal distribution, the comparison of the results between groups (control and variants with the use of Verva and Verva-spruce) was carried out using Student's $t$-test. Differences were found to be significant at $\mathrm{p}$ $<0.05$.

\section{Discussion of results}

The analysis of morphometric parameters of seedlings, carried out at the end of the first growing season, showed significant differences in height in variants with the use of Verva at a dose of $0.25 \mathrm{ml} / \mathrm{kg}(3.0 \pm 0.08 \mathrm{~cm})$ and Verva-spruce at a dose of $0.1 \mathrm{ml} / \mathrm{kg}(2.8 \pm 0.14 \mathrm{~cm})$ and $0.25 \mathrm{ml} / \mathrm{kg}(3.0 \pm 0.14 \mathrm{~cm})$ against control variant $(2.3 \pm 0.11$ $\mathrm{cm})$. The height of seedlings in variant with the use of Verva at a dose of $0.1 \mathrm{ml} / \mathrm{kg}$ did not differ significantly from control value.

The height of 2-year-old seedlings, the length of the stem with needles, and the current growth of seedlings in the second year in experimental variants exceeded control ones (Tab. 1). The use of Verva and Verva-spruce resulted in a significant increase in stem diameter at the level of root collar and length of the stem with needles in comparison with the same parameters in control variant. The difference in these indicators remained in the following year of growth (Tab. 1, Fig.).

Due to the fact that during third growing season there was an active growth of stem and branches, while the mass of the roots increased slightly and mainly because of growth of secondary roots, the ratio of above-ground mass of spruce seedlings to underground mass increased significantly in third year of growth (Table 2). It is noted that the ratio «above-ground mass / underground mass» remained higher in almost all variants where the preparations were used.

Although the weather conditions in the first year after sowing, associated with low level of humidity, were not entirely favorable for the active growth of seedlings and it was resolved by irrigation, growth stimulants led to an increase in height of seedlings in most experimental options. Analysis of the seedlings growth in the following years of cultivation showed that the effects of Verva and Verva-spruce have a prolonged character. Single treatment of seeds before sowing increased morphometric parameters both in second and third year of vegetation.

Table 1. Morphometric value of 2 and 3-year-old seedlings of Siberian spruce

\begin{tabular}{|c|c|c|c|c|c|c|}
\hline \multirow[t]{2}{*}{ Parameters } & \multirow{2}{*}{$\begin{array}{l}\text { Seedling } \\
\text { age, year }\end{array}$} & \multirow[t]{2}{*}{ Control } & \multicolumn{2}{|c|}{ Dose of Verva, $\mathrm{ml} / \mathrm{kg}$ of seeds } & \multicolumn{2}{|c|}{$\begin{array}{c}\text { Dose of Verva-spruce, } \mathrm{ml} / \mathrm{kg} \text { of } \\
\text { seeds }\end{array}$} \\
\hline & & & 0.1 & 0.25 & 0.1 & 0.25 \\
\hline \multirow{2}{*}{$\begin{array}{l}\text { Stem diameter at the } \\
\text { level of a root collar, } \\
\mathrm{mm}\end{array}$} & 2 & $1.2 \pm 0.04 \mathrm{a}^{*}$ & $1.2 \pm 0.04 \mathrm{a}$ & $1.4 \pm 0.04 \mathrm{~b}$ & $1.3 \pm 0.05 \mathrm{a}$ & $1.5 \pm 0.06 \mathrm{~b}$ \\
\hline & 3 & $1.5 \pm 0.04 \mathrm{a}$ & $1.8 \pm 0.06 \mathrm{~b}$ & $2.0 \pm 0.06 \mathrm{~b}$ & $1.9 \pm 0.08 \mathrm{~b}$ & $1.8 \pm 0.06 \mathrm{~b}$ \\
\hline \multirow{2}{*}{ Stem height, cm } & 2 & $6.3 \pm 0.32 \mathrm{a}$ & $7.8 \pm 0.57 b$ & $9.4 \pm 0.41 \mathrm{~b}$ & $7.5 \pm 0.39 b$ & $9.8 \pm 0.59 b$ \\
\hline & 3 & $12.7 \pm 0.30 \mathrm{a}$ & $14.9 \pm 0.49 b$ & $16.0 \pm 0.52 b$ & $14.5 \pm 0.58 b$ & $16.6 \pm 0.50 \mathrm{~b}$ \\
\hline \multirow{2}{*}{$\begin{array}{l}\text { Length of the stem with } \\
\text { needles, } \mathrm{cm}\end{array}$} & 2 & $5.4 \pm 0.31 \mathrm{a}$ & $6.8 \pm 0.58 b$ & $8.4 \pm 0.40 \mathrm{~b}$ & $6.6 \pm 0.38 b$ & $8.6 \pm 0.57 \mathrm{~b}$ \\
\hline & 3 & $11.1 \pm 0.28 \mathrm{a}$ & $13.4 \pm 0.46 b$ & $14.4 \pm 0.49 \mathrm{~b}$ & $13.2 \pm 0.58 b$ & $14.9 \pm 0.47 b$ \\
\hline \multirow{2}{*}{ Current growth, $\mathrm{cm}$} & 2 & $4.0 \pm 0.27 \mathrm{a}$ & $5.5 \pm 0.51 \mathrm{~b}$ & $6.4 \pm 0.34 \mathrm{~b}$ & $4.8 \pm 0.29 b$ & $6.9 \pm 0.51 b$ \\
\hline & 3 & $5.5 \pm 0.14 \mathrm{a}$ & $6.8 \pm 0.22 b$ & $7.7 \pm 0.29 b$ & $7.5 \pm 0.30 \mathrm{~b}$ & $7.2 \pm 0.24 \mathrm{~b}$ \\
\hline \multirow{2}{*}{$\begin{array}{l}\text { Length of a primary } \\
\text { root, cm }\end{array}$} & 2 & $20.0 \pm 0.81 \mathrm{a}$ & $18.4 \pm 0.78 \mathrm{a}$ & $19.1 \pm 0.70 \mathrm{a}$ & $19.2 \pm 0.63 \mathrm{a}$ & $21.8 \pm 0.90 \mathrm{a}$ \\
\hline & 3 & $20.4 \pm 0.44 \mathrm{a}$ & $20.7 \pm 0.59 \mathrm{a}$ & $21.9 \pm 0.49 \mathrm{~b}$ & $21.0 \pm 0.49 \mathrm{a}$ & $22.4 \pm 0.54 \mathrm{~b}$ \\
\hline
\end{tabular}

* Here and in the table 2, the data is presented as an arithmetic mean with a standard error. Statistically significant differences $(\mathrm{p}<0.05)$ in the studied parameters between the control and experimental variants are shown in different letters. 


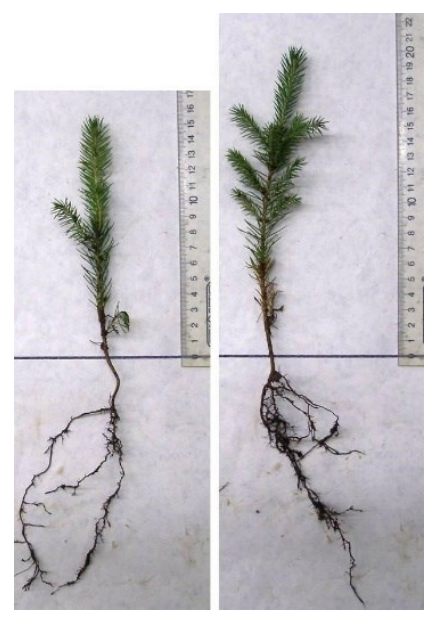

a
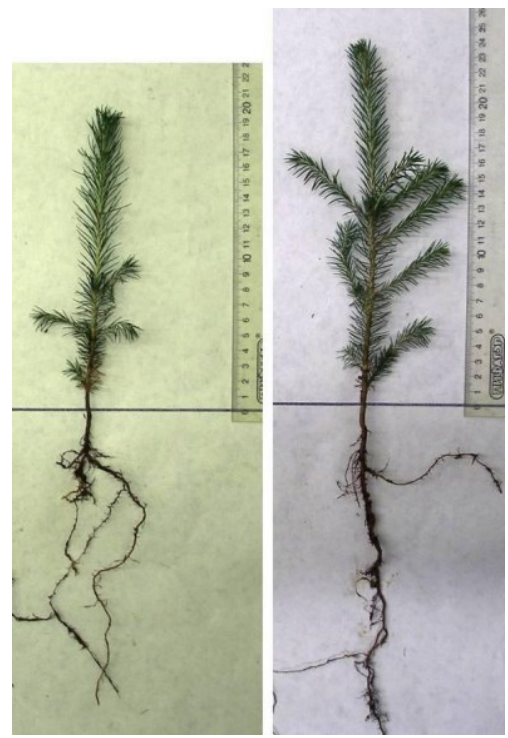

$\mathrm{b}$

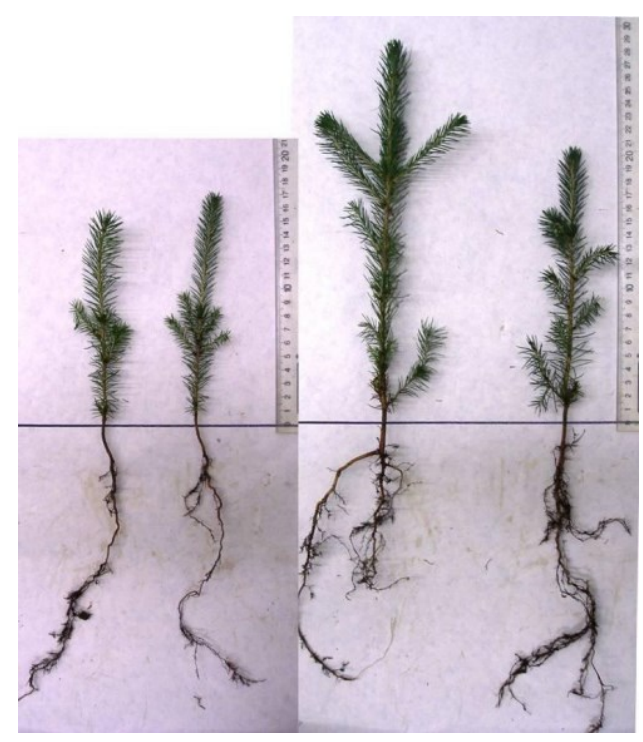

$\mathrm{c}$

Figure. 3-year-old Siberian spruce seedlings: a) control, b) with the use of Verva at a dose of $0.25 \mathrm{ml} / \mathrm{kg}$, c) with the use of Verva-spruce at a dose of $0.25 \mathrm{ml} / \mathrm{kg}$

Table 2. Value of phytomass of above-ground and underground parts of seedlings Siberian spruce

\begin{tabular}{l|c|c|c|c|c|c}
\hline \multirow{2}{*}{$\begin{array}{c}\text { Parameters } \\
\text { Seedling }\end{array}$} & \multirow{2}{*}{$\begin{array}{c}\text { Control } \\
\text { age, year }\end{array}$} & & \multicolumn{2}{|c|}{ Dose of Verva, ml/kg of seeds } & \multicolumn{2}{c}{$\begin{array}{c}\text { Dose of Verva-spruce, } \mathrm{ml} / \mathrm{kg} \text { of } \\
\text { seeds }\end{array}$} \\
\cline { 4 - 7 } & & 0.1 & 0.25 & 0.1 & 0.25 \\
\hline Above-ground mass, g & 2 & $0.16 \pm 0.02 \mathrm{a}$ & $0.18 \pm 0.02 \mathrm{a}$ & $0.23 \pm 0.02 \mathrm{~b}$ & $0.21 \pm 0.03 \mathrm{a}$ & $0.33 \pm 0.04 \mathrm{~b}$ \\
& 3 & $0.46 \pm 0.03 \mathrm{a}$ & $0.65 \pm 0.06 \mathrm{~b}$ & $0.71 \pm 0.06 \mathrm{~b}$ & $0.71 \pm 0.08 \mathrm{~b}$ & $0.62 \pm 0.05 \mathrm{~b}$ \\
Underground mass, g & 2 & $0.13 \pm 0.02 \mathrm{a}$ & $0.10 \pm 0.01 \mathrm{a}$ & $0.13 \pm 0.01 \mathrm{a}$ & $0.14 \pm 0.01 \mathrm{a}$ & $0.23 \pm 0.02 \mathrm{~b}$ \\
& 3 & $0.22 \pm 0.01 \mathrm{a}$ & $0.26 \pm 0.02 \mathrm{a}$ & $0.28 \pm 0.02 \mathrm{~b}$ & $0.32 \pm 0.04 \mathrm{~b}$ & $0.22 \pm 0.02 \mathrm{a}$ \\
The ratio of above-ground & 2 & $1.38 \pm 0.07 \mathrm{a}$ & $1.74 \pm 0.13 \mathrm{~b}$ & $1.85 \pm 0.11 \mathrm{~b}$ & $1.46 \pm 0.1 \mathrm{a}$ & $1.42 \pm 0.08 \mathrm{a}$ \\
mass to underground mass & 3 & $2.19 \pm 0.07 \mathrm{a}$ & $2.53 \pm 0.07 \mathrm{~b}$ & $2.56 \pm 0.08 \mathrm{~b}$ & $2.11 \pm 0.06 \mathrm{a}$ & $2.96 \pm 0.07 \mathrm{~b}$ \\
\hline
\end{tabular}

In general, by the end of the third year of cultivation, the main parameters of seedlings in all variants have reached and even exceeded the values specified in the Rules for Reforestation, according to which 3-4-year-old Picea obovata seedlings should have at least $1.5 \mathrm{~mm}$ stem diameter at the level of a root collar and stem height not less than $10.0 \mathrm{~cm}$ [22]. The latter can significantly increase the profitability of obtaining planting material.

More active accumulation of phytomass of the above-ground part under the influence of stimulants in comparison with the underground part also indicates a prolonged nature of the effect of the studied drugs on seedlings Picea obovata. The effect of the Pinus sylvestris L. seedlings aboveground and underground parts masses ratio increase under the influence of foliar feeding with a coniferous preparation obtained on the basis of woody greenery of Pinus sylvestris and Picea abies was noted in [24]. There is no information about the stimulating effect of flavonoids on phytomass and plant growth indicators of spruce in the literature related to the research topic. The slower formation of the root system of spruce at the age of 3 years can be considered in two ways. On the one hand, a more compact root system is more convenient for seedlings transplantation to forest conditions, but on the other, subsequently, its small size can negatively affect the stability of seedlings. Thus, further observations of growth and formation of roots in seedlings obtained from spruce seedlings with the use of Verva and Verva-spruce are required.

\section{Conclusion}

The results of the study showed that Siberian spruce seedlings grown from seeds treated with natural drugs containing triterpene acids and flavonoids before sowing had a higher growth rate (seedling height, stem diameter at the level of a root collar) during three years of cultivation under forest nursery conditions compared to control plants. Three-year-old seedlings of spruce grown with the use of stimulants Verva and Verva-spruce, exceeded the 
control seedlings in height by 20-30\%, and in thickness of stem - by 19-20\%. Experimental seedlings of Picea obovata showed a tendency for a better development of the above-ground parts.

Biological products Verva and Verva-spruce can be recommended for use in forest nurseries as an effective growth stimulant for growing Picea obovata planting material.

\section{References}

1. Gosudarstvennyy katalog pestitsidov i agrokhimikatov, razreshennykh k primeneniyu na territorii Rossiyskoy Federatsii 2019. [State catalogue of pesticides and agrochemicals permitted for use on the territory of the Russian Federation 2019]. URL: www.agroxxi.ru/goshandbook. (in Russ.).

2. Bulgari R., Cocetta G., Trivellini A., Vernieri P., Ferrante A. Biol Agric Hortic., 2015, vol. 31(1), pp. 1-17. DOI: 10.1080/01448765.2014.964649.

3. Calvo P., Nelson L., Kloepper J.W. Plant Soil, 2014, vol. 383, pp. 3-41. DOI: 10.1007/s11104-014-2131-8.

4. Canellas L.P., Olivares F.L., Aguiar N.O., Jones D.L., Nebbioso A., Mazzei P., Piccolo A. Sci. Hortic., 2015, vol. 196, pp. 15-27. DOI: 10.1016/j.scienta.2015.09.013.

5. Khan W., Rayirath U.P., Subramanian S., Jithesh M.N., Rayorath P., Hodges D.M., Critchley A.T., Craigie J.S., Norrie J., Prithiviraj B. J. Plant Growth Regul., 2009, vol. 28(4), pp. 386-399. DOI: 10.1007/s00344-009-9103-x.

6. McCarthy N., Bentsen N.S., Willoughby I., Balandier P. Eur. J. Forest Res., 2011, vol. 130, pp. 7-16. DOI: 10.1007/s10342-010-0429-5.

7. Landis T.D. National proceedings: forest and conservation nursery associations - 2010. Proc. RMRS-P-65. Fort Collins, CO: USDA Forest Service, Rocky Mountain Research Station, pp. 61-66.

8. Howe A.A., Landhäusser S.M., Burney O.T., Long J.N., Mock K.E. New For., 2020, vol. 51, pp. 367-378. DOI: 10.1007/s11056-019-09727-8.

9. Alfredsen G., Solheim H., Slimestad R. Eur. J. Forest Res., 2008, vol. 127, pp. 387-393. DOI: 10.1007/s10342-0080222-x.

10. Malykhin E.V., Vaganova T.A., Kukina T.P., Popov S.A., Chibiryaev A.M. Chemistry for Sustainable Development, 2007, vol. 15, pp. 287-303.

11. Saskevich P.A., Mirenkov Yu.A., Kazharski V.R., Duktov V.P., Kozlov S.N., Vlasov A.G., Gurikova E.I. Rekomendacii proizvodstvu dlya sel'skohozyajstvennyh organizacij. [Recommendations for production for agricultural organizations]. Gorki, 2006, 28 p. (in Russ.).

12. Nagel R., Berasategui A., Paetz C., Gershenzon J., Schmidt A. Plant Physiol., 2014, vol. 164, pp. 555-569. DOI: 10.1104/pp.113.228940.

13. Khurshkaynen T.V., Kutchin A.V. Izvestiya Komi nauchnogo tsentra UrO RAN, 2011, no.1, pp. 17-23. (in Russ.).

14. Tulinov A.G. Zashchita i karantin rasteniy, 2017, no. 2, pp. 41-42. (in Russ.).

15. Larin V.B. Kul'tury yeli i kedra sibirskogo na severo-vostoke yevropeyskoy chasti SSSR [Cultures of spruce and Siberian pine in the northeast of the European part of the USSR]. Leningrad, 1980, 224 p. (in Russ.).

16. Kavosi M.R. Lesnoy vestnik, 2006, no. 2, pp. 161-166. (in Russ.).

17. Pentelkina N.V. Aktual'nyye problemy lesnogo kompleksa, 2012, no. 31, pp. 189-193. (in Russ.).

18. Kirienko M.A., Goncharova I.A. Sib. J. For., 2018, no. 1, pp. 65-70. DOI: 10.15372/SJFS20180107.

19. Zubarev A.A., Kargin I.F., Papkov A.N. Kartofel' i ovoshchi, 2012, no. 5, p. 7. (in Russ.).

20. Andreeva E.M., Stetsenko S.K., Kutchin A.V., Terekhov G.G., Khurshkainen T.V. Lesotekhnicheskiy zhurnal, 2016, no. 3, pp. 10-19. DOI: 12737/21675. (in Russ.).

21. Khurshkainen T.V., Andreeva E.M., Stetsenko S.K., Terekhov G.G., Kutchin A.V. Khimiya rastitel'nogo syr'ya, 2019, no. 1, pp. 295-300. DOI: 10.14258/jcprm.2019014248. (in Russ.).

22. Pravila lesovosstanovleniya. [Rules for reforestation]. 2016, no. 375, 146 p. (in Russ.).

23. Kolesnicov B.P., Zubareva R.S., Smologonov E.P. Lesnyye porody i tipy lesov Sverdlovskoy oblasti: prakticheskoye posobiye [Forest Species and Types of Forest in the Sverdlovsk Region: A Practical Guide]. Sverdlovsk, 1973, 176 p. (in Russ.).

24. Egorova A.V., Chernobrovkina N.P., Robonen E.V. Khimiya rastitel'nogo syr'ya, 2017, no. 2, pp. 171-180. DOI: 10.14258/jcprm.2017021720. (in Russ.).

Received November 19, 2020

Revised December 25, 2020

Accepted April 13, 2021

For citing: Khurshkainen T.V., Stetsenko S.K., Andreeva E.M., Terekhov G.G., Kutchin A.V. Khimiya Rastitel'nogo Syr'ya, 2021, no. 3, pp. 329-333. (in Russ.). DOI: 10.14258/jcprm.2021038854. 
